Brief Report

\title{
Female Mice Reaching Exceptionally High Old Age Have Preserved 20S Proteasome Activities
}

\author{
Irene Martínez de Toda ${ }^{1,2}$, Suresh I. S. Rattan ${ }^{3}\left(\mathbb{D}\right.$, Mónica De la Fuente ${ }^{1,2}$ and Lorena Arranz ${ }^{1, *,+(\mathbb{D})}$ \\ 1 Department of Genetics, Physiology and Microbiology (Unit of Animal Physiology), Faculty of Biology, \\ Complutense University, 28040 Madrid, Spain; imtcabeza@ucm.es (I.M.d.T.); mondelaf@bio.ucm.es (M.D.1.F.) \\ 2 Institute of Investigation Hospital 12 Octubre, 28041 Madrid, Spain \\ 3 Department of Molecular Biology and Genetics, Århus University, 8000 Århus, Denmark; rattan@mbg.au.dk \\ * Correspondence: lorena.arranz@uit.no \\ + Current address: Stem Cells, Ageing and Cancer Research Group, Department of Medical Biology, Faculty of \\ Health Sciences, UiT—The Arctic University of Norway, MH2 Building Level 10, 9019 Tromsø, Norway.
}

Citation: Martínez de Toda, I.; Rattan, S.I.S.; De la Fuente, M.; Arranz, L. Female Mice Reaching Exceptionally High Old Age Have Preserved 20S Proteasome Activities. Antioxidants 2021, 10, 1397. https:// doi.org/10.3390/antiox10091397

Academic Editor: Stanley Omaye

Received: 28 July 2021

Accepted: 28 August 2021

Published: 31 August 2021

Publisher's Note: MDPI stays neutral with regard to jurisdictional claims in published maps and institutional affiliations.

Copyright: (c) 2021 by the authors. Licensee MDPI, Basel, Switzerland. This article is an open access article distributed under the terms and conditions of the Creative Commons Attribution (CC BY) license (https:// creativecommons.org/licenses/by/ $4.0 /)$.

\begin{abstract}
Oxidized, damaged and misfolded proteins accumulate during aging and contribute to impaired cell function and tissue homeodynamics. Damaged proteins are degraded by cellular clearance mechanisms like the $20 \mathrm{~S}$ proteasome. Aging relates to low $20 \mathrm{~S}$ proteasome function, whereas long-lived species show high levels. However, contradictory results exist depending on the tissue or cell type and it is unknown how the $20 \mathrm{~S}$ proteasome functions in exceptionally old mice. The aim of this study was to investigate two proteasome activities (caspase-like and chymotrypsin-like) in several tissues (lung, heart, axillary lymph nodes, liver, kidney) and cells (peritoneal leukocytes) from adult (28 \pm 4 weeks, $n=12)$, old (76 \pm 4 weeks, $n=9)$ and exceptionally old (128 \pm 4 weeks, $n=9)$ $\mathrm{BALB} / \mathrm{c}$ female mice. The results show different age-related changes depending on the tissue and the activity considered, so there is no universal decline in proteasome function with age in female mice. Interestingly, exceptionally old mice displayed better maintained proteasome activities, suggesting that preserved $20 \mathrm{~S}$ proteasome is associated with successful aging.
\end{abstract}

Keywords: aging; healthy aging; exceptionally old; 20 S proteasome; caspase-like activity; chymotrypsinlike activity

\section{Introduction}

Accumulation of damage in DNA, RNA and proteins is one of the universal features of aging. Whatever the causative agents and the source of the damage, increased molecular heterogeneity and the resulting impairment of functions at all levels of organization are hallmarks of aging [1-3]. In the case of proteins, damaged, modified and abnormal proteins accumulate, aggregate and interfere with normal cellular functions [4]. Therefore, an efficient cellular function requires balance between protein synthesis/folding, and degradation of misfolded or damaged proteins, termed proteostasis or proteodynamics [5].

The two main protein degradation systems are the autophagy pathway through the lysosomes and the proteasome system [5]. The proteasome is an evolutionary conserved multi-subunit protein complex [6]. The four-ringed 20S proteasome is the basic or core form, to which two $19 S$ regulators are added to form the $26 S$ proteasome [7]. Each eukaryotic $20 S$ core particle has three pairs of proteolytic sites with distinct substrate specificities [8]. The $\beta 5$ proteolytic sites are "chymotrypsin-like" (CT-like); the $\beta 2$ sites are "trypsin-like" (T-like); and the $\beta 1$ sites cleave after acidic residues (Glu, Asp) and are referred to as "post-acidic" PGPH ("post-glutamate peptide hydrolase"), or "caspase-like" (C-like). In the past, the $20 \mathrm{~S}$ proteasome was seen as a mere component of the $26 \mathrm{~S}$ proteasome complex, mediating degradation of ubiquitin-tagged proteins. New emerging evidence indicates that the 20S proteasome alone is responsible for cell clearance of abnormal, denatured or in general damaged proteins, and fine-tuned degradation of short-lived proteins [9]. In the 
absence of 195 regulators, the 20S proteasome specifically unfolds damaged or oxidized proteins in an ATP/ubiquitin-independent manner by recognition of hydrophobic domains exposed to the aqueous environment [7]. This seems to be the main function of the 20S proteasome [6,9] and therefore, the study of its activity is relevant in the context of aging.

Several studies indicate decline of the 20S proteasome activity with age that depends on at least three different mechanisms: decreased proteasome expression, alterations and/or replacement of proteasome subunits and formation of inhibitory cross-linked proteins [10]. Peptidase activities decrease with age in a variety of tissues and cells such as lymphocytes [11], fibroblasts [12] and muscle [13,14] from rodents, human lens [15] and fireflies [16]. However, sometimes contradictory results were reported, and some authors found no changes in any of the three peptidase activities with age [17] whereas others found decreased CT-like activity in liver from rats $[17,18]$. In human lymphocytes, decreased agerelated specific activity of the 26 proteasome is associated with increased post-translational modifications, whereas levels and subunit composition are unaffected [19]. In turn, human aging epidermis show both decreased content and alterations in subunits contributing to decreased activity of the $20 \mathrm{~S}$ proteasome $[20,21]$.

Conversely, long-lived animals, such as long-lived bat species, show high expression levels of the 20S proteasome subunits. These are related to less accumulation of oxidized proteins and greater resistance to oxidative stress [22]. Similarly, naked mole rats (which are the longest living rodent species) display very high expression of the $20 \mathrm{~S}$ proteasome, resulting in better oxidative stress resistance compared to other rodents [23]. Besides interspecies differences, the study of the 20S proteasome in exceptionally old individuals (which presumably experience "healthy aging") in comparison to those that achieve average life span from the same species, can help further elucidate its role in aging and longevity. For example, fibroblast cultures from centenarians exhibit proteasome subunit expression, C-like activity and levels of oxidized proteins more similar to younger rather than older donors [24].

To gain further insight into the activity of the 20S proteasome in aging and longevity, the aim of the present work was to investigate two different proteasome activities (CT-like and C-like) in several tissues (heart, lung, liver, kidney, axillary lymph nodes) and cells (peritoneal leukocytes) from adult, old and exceptionally old BALB/c female mice.

\section{Materials and Methods}

\subsection{Experimental Animals}

We used 30 female BALB/c mice (Mus musculus), purchased from Harlan Ibérica (Barcelona, Spain), at a young adult age ( $28 \pm 4$ weeks). The mice were specifically pathogen free as tested by Harlan and according to the Federation of European Laboratory Science Associations recommendations. In our animal facility, placed at the Faculty of Biology (UCM), they were housed at $6 \pm 1$ per cage and maintained at a constant temperature $\left(22 \pm 2{ }^{\circ} \mathrm{C}\right)$ in sterile conditions inside an aseptic air negative pressure environmental cabinet (Flufrance, Cachan, France), on a 12/12 h reversed light/dark cycle (lights on at $8 \mathrm{pm}$ ). Mice had access to tap water and standard Sander Mus pellets (A04 diet; Panlab, Barcelona, Spain) ad libitum. Diet was in accordance with the recommendations of the American Institute of Nutrition for laboratory animals.

This cross-sectional study, defined as a study that takes place at a single point in time, was performed simultaneously on mice of different ages, namely adult ( $28 \pm 4$ weeks, $n=12$ ), old (76 \pm 4 weeks, $n=9)$ and exceptionally old (128 \pm 4 weeks, $n=9)$, which had aged in our animal unit under the above specified conditions from the adult age. Each age group category was formed by animals that had been purchased in the same set. The exceptionally old mice had naturally achieved healthy and successful aging, since the average life span for females of BALB/c mice strain in our animal house was $99 \pm 5$ weeks [25]. The percentage of these females that reach exceptionally old age was approximately $7 \%-10 \%$. Not all animals provided the full set of data. Mice were treated according to the guidelines of the European Community Council Directives (86/6091 EEC). They were sacrificed by rapid cervical dislocation during the 
dark phase of the cycle (08:00-10:00 a.m.). Heart, lung, liver, kidney, axillary lymph nodes and peritoneal leukocytes were removed aseptically and immediately frozen down at $-80{ }^{\circ} \mathrm{C}$ until further processing.

\subsection{Preparation of Tissue Lysates}

To preserve proteasome activity, native protein lysates were obtained by resuspension of frozen tissue and cell pellets in buffer containing $50 \mathrm{mM} \mathrm{NaCl}, 10 \mathrm{mM}$ HEPES $\mathrm{pH}$, $500 \mathrm{mM}$ Sucrose, $1 \mathrm{mM}$ EDTA, $0.2 \%$ Triton 100X, $0.2 \mathrm{mM}$ phenylmethanesulfonyl fluoride (PMSF) and $7.2 \mathrm{mM} \beta$-mercaptoetanol. Cell debris was removed by centrifugation and protein concentration was assessed in the supernatant using the bicinchoninic acid Protein Assay Kit protocol (BCA, Sigma).

\subsection{Proteasome Activity Assay}

Peptides used for determination of proteasome CT-like and C-like activities were Succinyl-leucine-leucine-valine-tyrosine-7-Amino-4-Methylcoumarin (Suc-LLVY-AMC) and Carboxybenzyl-Leu-Leu-Glu-7-Amino-4-Methylcoumarin (Z-LLE-AMC), respectively. Suc-LLVY-AMC or Z-LLE-AMC were added to a flat-bottom 96-well plate at a final concentration of $25 \mu \mathrm{M}$ or $150 \mu \mathrm{M}$, respectively, together with the tissue/cell lysates adjusted to different protein concentrations, depending on the tissue, in order to measure linear kinetics of proteasome activity and ensure saturation was not reached during the course of the assay, in a final volume of $200 \mu \mathrm{L}$ in 1 M HEPES pH 8. Protein amounts used were $60 \mu \mathrm{g}$ for heart; $20 \mu \mathrm{g}$ for liver, axillary nodes and peritoneal leukocytes; $10 \mu \mathrm{g}$ for lung; and $2 \mu \mathrm{g}$ for kidney. All measurements were made in triplicate, and samples for comparisons were run in the same test. For each individual and proteasome activity measurement, a negative control was performed in duplicate by adding a specific inhibitor of proteasome activity (MG132) at a final concentration of $400 \mu \mathrm{M}$. To detect the activity of the $20 \mathrm{~S}$ proteasome, ATP was not added to the reaction mixtures.

The reading was performed in a plate reader with a $380 \mathrm{~nm}$ excitation filter and a $460 \mathrm{~nm}$ emission filter. The plate was incubated inside the fluorimeter for $50 \mathrm{~min}$, and during this time, 25 reading cycles were performed, 1 cycle every $120 \mathrm{~s}$. The respective activity in the presence of MG132 was subtracted from each sample to obtain the specific activity (fluorescence arbitrary units per time in seconds). Results were expressed as specific activity/mg protein.

Trypsin-like activity was not measured due to high interference of non-proteasome mediated trypsin-like activities in biological samples where the proteasome was not purified $[26,27]$.

\subsection{Statistical Analysis}

Data are expressed as mean \pm standard deviation (SD). The normality of the samples and the homogeneity of variances were checked by the Kolmogorov-Smirnov and Levene analyses, respectively. Differences due to age were studied through the one-way analysis of variance. The Tukey test with a level of significance set at $p<0.05$ was used for post-hoc comparisons when variances were homogeneous, whereas its counterpart analysis GamesHowell set at the same significance level was used with unequal variances. Differences versus adult age are shown.

\section{Results}

Figure 1 shows results for C-like activity in adult, old and exceptionally old female mice. Old mice displayed lower C-like activity in lung $(236.84 \pm 69.87)$ and heart $(53.60 \pm 7.65)$ in comparison with adults $(337.96 \pm 60.45,70.71 \pm 9.22$, respectively), whereas in liver, kidney and peritoneal leukocytes, old mice showed higher $(263.74 \pm 76.77,418.85 \pm 96.45,141.87 \pm 81.40$, respectively) C-like activity than adults $(184.77 \pm 54.94,301.85 \pm 110.33,48.79 \pm 21.82$, respectively; $p<0.05)$. Axillary lymph nodes showed unchanged values with age (129.44 \pm 10.51 in adult, $108.17 \pm 22.59$ in old and $141.33 \pm 57.12$ in exceptionally old). Exceptionally old mice 
exhibited similar C-like activities to adults in lung (275.08 \pm 63.90$)$, liver (242.38 \pm 46.56$)$ and kidney (308.95 \pm 65.25$)$, plus axillary lymph nodes. Like old mice, exceptionally old mice showed lower $(56.38 \pm 9.66)$ C-like activity in heart $(p<0.01)$ and higher $(198.33 \pm 72.06)$ in peritoneal leukocytes $(p<0.05)$ than adults.

Lung

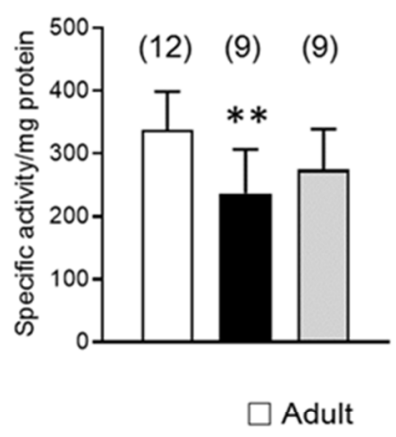

Liver

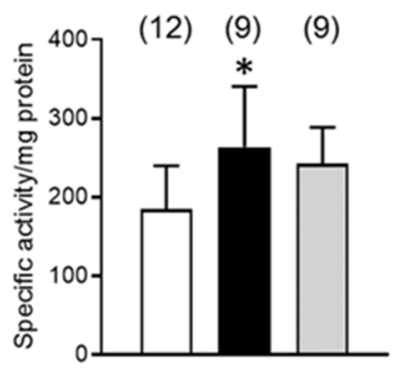

Heart

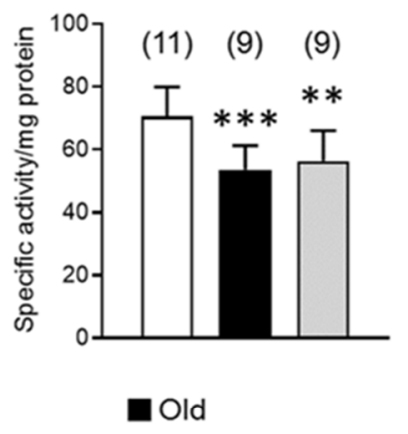

Kidney

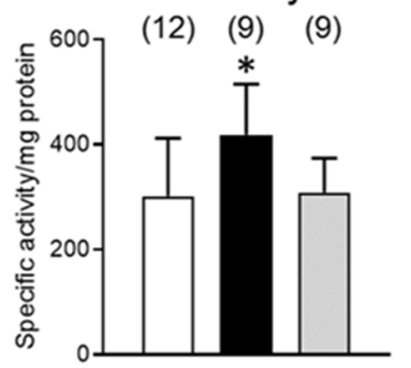

Axillary Lymph Nodes

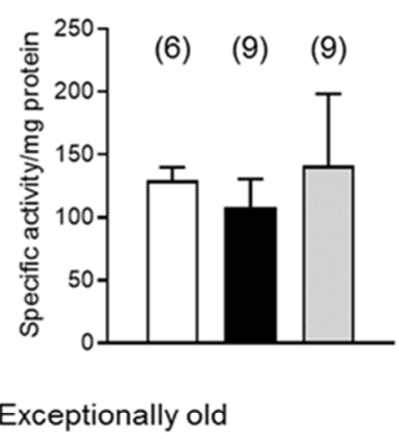

Peritoneal Leukocytes

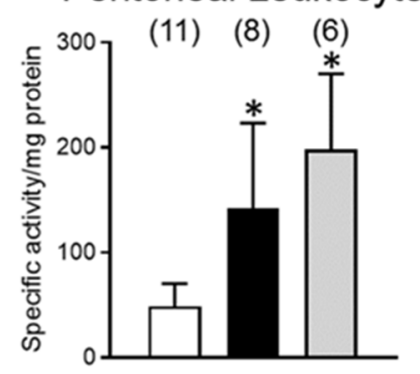

Figure 1. Age-related changes in caspase-like (C-like) activity in different tissues: Lung; heart; axillary lymph nodes; liver; kidney; peritoneal leukocytes. Adult ( $28 \pm 4$ weeks); old (76 \pm 4 weeks); exceptionally old (128 \pm 4 weeks). Numbers of animals used for each experimental group and biological sample are in brackets. ${ }^{*} p<0.05 ;{ }^{* *} p<0.01$; ${ }^{* *} p<0.001$, with respect to adult mice.

Figure 2 shows results for CT-like activity in adult, old and exceptionally old female mice. Old mice displayed lower CT-like activity in lung $(719.04 \pm 295.77)$ and kidney $(466.85 \pm 249.30)$ in comparison with adults (1086.47 $\pm 252.50,938.35 \pm 290.98$, respectively; $p<0.01)$. Conversely, old mice had higher CT-like activity in liver $(134.13 \pm 36.24 ; p<0.05)$ and peritoneal leukocytes $(471.34 \pm 187.64 ; p<0.01)$ than adult mice $(88.53 \pm 26.05,186.82 \pm 93.60$, respectively). No differences were found in heart and axillary lymph nodes with age (15.54 \pm 6.43 in adult, $11.50 \pm 12.48$ in old and $21.59 \pm 4.71$ in exceptionally old in heart, and $409.61 \pm 140.53$ in adult, $240.17 \pm 71.97$ in old and $335.85 \pm 211.08$ in exceptionally old in axillary lymph nodes). Exceptionally old mice showed similar CT-like activity to adults in lung (826.51 \pm 198.39$)$ and peritoneal leukocytes $(473.36 \pm 370.80)$. Likewise, exceptionally old mice had unchanged CTlike activity in heart and axillary lymph nodes with respect to adults. CT-like activity showed similar trends to old in exceptionally old age in kidney (509.60 \pm 307.95$)$ and liver (162.26 \pm $46.62)$ with lower $(p<0.01)$ and higher values $(p<0.001)$ respectively, compared to adult mice. 

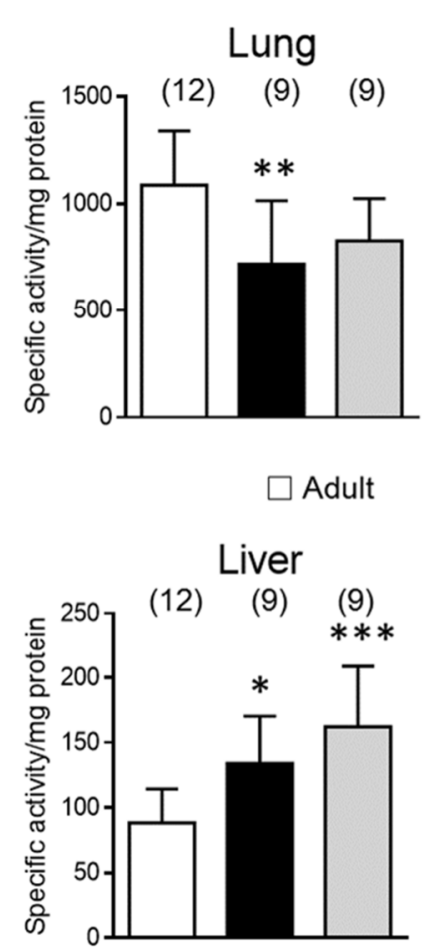
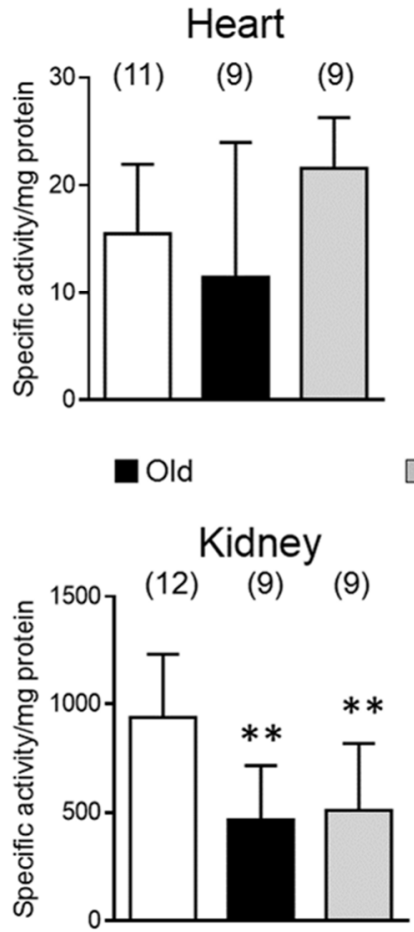

Axillary Lymph Nodes

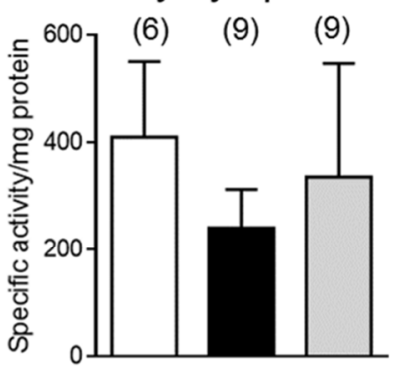

$\square$ Exceptionally old

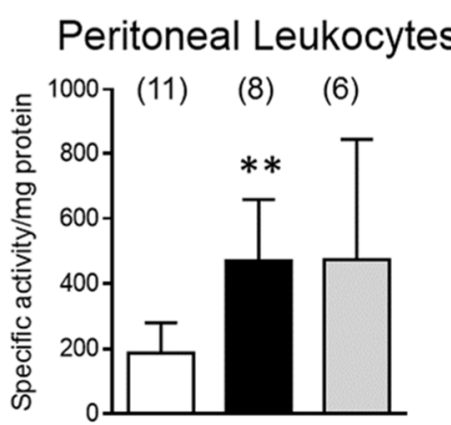

Figure 2. Age-related changes in chymotrypsin-like (CT-like) activity in different tissues: Lung; heart; axillary lymph nodes; liver; kidney; peritoneal leukocytes. Adult ( $28 \pm 4$ weeks); old (76 \pm 4 weeks); exceptionally old (128 \pm 4 weeks). Numbers of animals used for each experimental group and biological sample are in brackets. ${ }^{*} p<0.05$; ${ }^{* *} p<0.01$; ${ }^{* * *} p<0.001$, with respect to adult mice.

\section{Discussion}

The present study shows relevant and complex age-related changes in C-like and CTlike activities of the $20 \mathrm{~S}$ proteasome. These changes show strong particularities depending on the organ and peptidase activity considered. Some proteasome activities were lower in old mice in comparison with adult mice, such as the C-like activity in lungs and heart, and the CT-like activity in lungs and kidney. These results are in agreement with previous studies $[28,29]$ and with the general concept that age-related accumulation of damaged and dysfunctional proteins results, at least partially, from an impairment of the protein degradation pathways with age.

However, other proteasome activities were higher in old mice in comparison with adults, such as the C-like activity in liver, kidney and peritoneal leukocytes and the CT-like activity in liver and peritoneal leukocytes, in agreement with some previous studies $[17,30]$. The liver and kidney play key detoxifying functions, and peritoneal leukocytes are recruited into the peritoneal cavity to prevent peritoneal infection through activating pro-inflammatory cytokines and chemokines [31]. In these tissues, age-related high proteasome activities could reflect a compensatory mechanism to the high loads of oxidative stress and oxidized proteins, given that the proteasome activity is modulated by oxidative stress [32]. In fact, these tissues are also great reservoirs of antioxidant defenses that may help scavenging free radicals and contribute to lowering the levels of oxidized proteins $[33,34]$. Future work should evaluate these hypotheses and test to what extent the higher proteasome activities in liver, kidney and peritoneal leukocytes at old age are efficient in counteracting the accumulation of damaged proteins.

The net differential degree of age-related oxidative stress affecting tissues may be a relevant source of tissue-specific differences. Indeed, under normal conditions, the greater the proteasome activation, the greater the oxidative stress. However, if the oxidative stress is too high, the proteasome may be inhibited [35,36]. Additionally, the machinery of protein quality control is also tissue-specific and may contribute to variability in proteasome activity among tissues, including, for example, the expression of heat-shock proteins [37]. 
Of note, our observations do not ascertain the underlying mechanisms responsible for the age-related changes in $20 S$ proteasome activities, e.g., proteasome subunit expression, translation and/or assembly, and/or regulation of activity by, for example, formation of inhibitory complexes [10]. Future work is required to clarify these aspects.

Overall, exceptionally old mice had similar peptidase activities to adult mice in most tissues investigated, suggesting that preserved 20S proteasome function correlates with achieving extreme old age. Exceptionally old mice showed lower C-like activity in the heart and CT-like activity in the kidney, and higher CT-like activity in the liver and peritoneal leukocytes, in similar trends to old mice. Lower activities in exceptionally old animals may suggest relatively disposable functions in the context of reaching successful aging, whereas higher/preserved activities could reflect adaptive mechanisms underlying healthy aging. Consistent with this idea, longevity was associated with higher CT-like activity in liver of naked mole rats compared to shorter-lived mice [38]. These interpretations should be considered with caution though, as the age-related changes in old and exceptionally old mice may occur at different rates and/or have different evolutions along the aging process. Future longitudinal studies will be needed to test those hypotheses. In addition, future work should investigate if the proteasome function in exceptionally old mice correlates inversely, in fact, with the level of accumulation of damaged proteins. Supporting this idea, a previous study demonstrated that peritoneal leukocytes from exceptionally old mice show higher basal levels of Hsp70 and lower accumulation of malondialdehyde, a marker of lipid peroxidative damage compared to old mice [39]. Further, protein oxidation markers in the brain and spleen from adult and exceptionally old mice showed similar levels, which were higher in old mice [25]. The mechanisms underlying better preserved $20 \mathrm{~S}$ proteasome activity in exceptionally old mice should be the focus of future work.

As an additional limitation of our study, proteasome activities were only investigated in female mice. Female mice were prioritized over males to promote research on females, because of the ease of caging them together as mice are a social species, and because females of virtually all species including mammals live longer than males [40-42]. The longer lifespan in females has been associated to multiple factors, and for example the heterogametic sex has been suggested to be more likely to express undesirable morphological and physiological characteristics [40]. Accumulated knowledge demonstrates that estrogen upregulates expression of antioxidant enzymes via the estrogen receptor and MAPK activation, which results in the upregulation of expression of longevity-related genes [42]. In comparative studies using tissues like heart, old male rats showed increased protein oxidative damage compared to old females [43]. Future studies should expand gender comparisons along the aging process to additional tissues, including both protein oxidative markers and 20S proteasome activity, and investigate whether exceptionally old male mice display maintained proteasome activity as well.

In fact, a pulse of estrogen in ovariectomized mice aimed at mimicking late diestrus II/early proestrus, stimulated the turn-over of certain proteins, including estrogen receptor alpha and $20 \mathrm{~S}$ proteasome chymotryptic activity in mammary glands in vivo [44]. In mammary glands from three-month-old female mice, the chymotryptic peptidase activity of the proteasome was elevated by about $40 \%$ during proestrus compared to the other stages [44]. It is uncertain whether the effects of estrogens during the estrus cycle extend to damaged proteins and additional tissues. To minimize potential effects of natural estrogen fluctuations in younger females, adult mice used here were seven months old, a stage where reproductive fertility starts to decay and diestrus stage is prolonged.

\section{Conclusions}

Together, our data show unique patterns of age-related changes in the $20 \mathrm{~S}$ proteasome activity and no universal decline in old female mice. Exceptionally old female mice displayed well-preserved $20 \mathrm{~S}$ proteasome activities. Although further analyses are needed to evaluate the role of the $20 \mathrm{~S}$ proteasome during the aging process, our study provides 
evidence that exceptionally old mice have sustained activity which may help achieve successful aging.

Author Contributions: Conceptualization, M.D.I.F. and L.A.; methodology, S.I.S.R. and L.A.; formal analysis, I.M.d.T. and L.A.; investigation, L.A.; resources, S.I.S.R., M.D.I.F. and L.A.; writing-original draft preparation, I.M.d.T. and L.A.; writing-review and editing, I.M.d.T., S.I.S.R., M.D.l.F. and L.A.; supervision, S.I.S.R., M.D.I.F. and L.A.; funding acquisition, M.D.l.F. and L.A. All authors have read and agreed to the published version of the manuscript.

Funding: This work was supported by a FPU scholarship from the Spanish Ministry of Science and Innovation (MICINN) and a mobility scholarship from the same program to L. Arranz, and FIS (PI15/01787) from the ISCIII-FEDER of the European Union and UCM-Research Group grants to M. De la Fuente. L. Arranz is currently supported by a joint meeting grant of the Northern Norway Regional Health Authority and UiT (2014/5668), Young Research Talent grants from the Research Council of Norway, (Stem Cell Program, 247596; FRIPRO Program, 250901), and grants from the Norwegian Cancer Society (6765150), and the Northern Norway Regional Health Authority (HNF1338-17). Further information and requests should be directed to the corresponding author, L. Arranz (lorena.arranz@uit.no).

Institutional Review Board Statement: Ethical protocol PROEX 373/15 approved by the ethics committee at Madrid Complutense University. Mice were treated according to the guidelines of the European Community Council Directives (86/6091 EEC). They were sacrificed by rapid cervical dislocation during the dark phase of the cycle (08:00-10:00 a.m.).

Informed Consent Statement: Not applicable.

Data Availability Statement: Data is contained within the paper.

Conflicts of Interest: The authors declare no conflict of interest.

\section{References}

1. Rattan, S.I. Theories of biological aging: Genes, proteins, and free radicals. Free Radic. Res. 2006, 40, 1230-1238. [CrossRef] [PubMed]

2. Rattan, S.I. Increased molecular damage and heterogeneity as the basis of aging. Biol. Chem. 2008, 389, 267-272. [CrossRef] [PubMed]

3. López-Otín, C.; Blasco, M.A.; Partridge, L.; Serrano, M.; Kroemer, G. The hallmarks of aging. Cell 2013, 153, 1194-1217. [CrossRef] [PubMed]

4. Rattan, S.I. Synthesis, modification and turnover of proteins during aging. Adv. Exp. Med. Biol. 2010, 694, 1-13.

5. Meyer-Schwesinger, C. The ubiquitin-proteasome system in kidney physiology and disease. Nat. Rev. Nephrol. 2019, 15, $393-411$. [CrossRef] [PubMed]

6. Raynes, R.; Pomatto, L.C.; Davies, K.J. Degradation of oxidized proteins by the proteasome: Distinguishing between the 20S, 26S, and immunoproteasome proteolytic pathways. Mol. Asp. Med. 2016, 50, 41-55. [CrossRef] [PubMed]

7. Pickering, A.M.; Davies, K.J. Degradation of damaged proteins: The main function of the $20 \mathrm{~S}$ proteasome. Prog. Mol. Biol. Transl. Sci. 2012, 109, 227-248.

8. Heinemeyer, W.; Fischer, M.; Krimmer, T.; Stachon, U.; Wolf, D.H. The active sites of the eukaryotic $20 \mathrm{~S}$ proteasome and their involvement in subunit precursor processing. J. Biol. Chem. 1997, 272, 25200-25209. [CrossRef]

9. Kumar Deshmukh, F.; Yaffe, D.; Olshina, M.A.; Ben-Nissan, G.; Sharon, M. The Contribution of the 20S Proteasome to Proteostasis. Biomolecules 2019, 9, 190. [CrossRef]

10. Carrard, G.; Bulteau, A.-L.; Petropoulos, I.; Friguet, B. Impairment of proteasome structure and function in aging. Int. J. Biochem. Cell Biol. 2002, 34, 1461-1474. [CrossRef]

11. Ponnappan, U.; Zhong, M.; Trebilcock, G.U. Decreased proteasome-mediated degradation in T cells from the elderly: A role in immune senescence. Cell Immunol. 1999, 192, 167-174. [CrossRef] [PubMed]

12. Beedholm, R.; Clark, B.F.; Rattan, S.I. Mild heat stress stimulates $20 \mathrm{~S}$ proteasome and its $11 \mathrm{~S}$ activator in human fibroblasts undergoing aging in vitro. Cell Stress Chaperones 2004, 9, 49-57. [CrossRef]

13. Husom, A.D.; Peters, E.A.; Kolling, E.A.; Fugere, N.A.; Thompson, L.V.; Ferrington, D.A. Altered proteasome function and subunit composition in aged muscle. Arch. Biochem. Biophys. 2004, 421, 67-76. [CrossRef] [PubMed]

14. Ferrington, D.A.; Husom, A.D.; Thompson, L.V. Altered proteasome structure, function, and oxidation in aged muscle. FASEB J. 2005, 19, 644-646. [CrossRef]

15. Viteri, G.; Carrard, G.; Birlouez-Aragón, I.; Silva, E.; Friguet, B. Age-dependent protein modifications and declining proteasome activity in the human lens. Arch. Biochem. Biophys. 2004, 427, 197-203. [CrossRef] [PubMed] 
16. Hansen, T.O.; Sarup, P.; Loeschcke, V.; Rattan, S.I. Age-related and sex-specific differences in proteasome activity in individual Drosophila flies from wild type, longevity-selected and stress resistant strains. Biogerontology 2012, 13, 429-438. [CrossRef] [PubMed]

17. Shibatani, T.; Nazir, M.; Ward, W.F. Alteration of rat liver $20 \mathrm{~S}$ proteasome activities by age and food restriction. J. Gerontol. A Biol. Sci. Med. Sci. 1996, 51, B316-B322. [CrossRef]

18. Friguet, B.; Bulteau, A.L.; Chondrogianni, N.; Conconi, M.; Petropoulos, I. Protein degradation by the proteasome and its implications in aging. Ann. N. Y. Acad. Sci. 2000, 908, 143-154. [CrossRef]

19. Carrard, G.; Dieu, M.; Raes, M.; Toussaint, O.; Friguet, B. Impact of ageing on proteasome structure and function in human lymphocytes. Int. J. Biochem. Cell Biol. 2003, 35, 728-739. [CrossRef]

20. Bulteau, A.L.; Petropoulos, I.; Friguet, B. Age-related alterations of proteasome structure and function in aging epidermis. Exp. Gerontol. 2000, 35, 767-777. [CrossRef]

21. Petropoulos, I.; Conconi, M.; Wang, X.; Hoenel, B.; Brégégère, F.; Milner, Y.; Friguet, B. Increase of oxidatively modified protein is associated with a decrease of proteasome activity and content in aging epidermal cells. J. Gerontol. A Biol. Sci. Med. Sci. 2000, 55, B220-B227. [CrossRef] [PubMed]

22. Salmon, A.B.; Leonard, S.; Masamsetti, V.; Pierce, A.; Podlutsky, A.J.; Podlutskaya, N.; Richardson, A.; Austad, S.N.; Chaudhuri, A.R. The long lifespan of two bat species is correlated with resistance to protein oxidation and enhanced protein homeostasis. FASEB J. 2009, 23, 2317-2326. [CrossRef] [PubMed]

23. Pérez, V.I.; Buffenstein, R.; Masamsetti, V.; Leonard, S.; Salmon, A.B.; Mele, J.; Andziak, B.; Yang, T.; Edrey, Y.; Friguet, B.; et al. Protein stability and resistance to oxidative stress are determinants of longevity in the longest-living rodent, the naked mole-rat. Proc. Natl. Acad. Sci. USA 2009, 106, 3059-3064. [CrossRef] [PubMed]

24. Chondrogianni, N.; Petropoulos, I.; Franceschi, C.; Friguet, B.; Gonos, E.S. Fibroblast cultures from healthy centenarians have an active proteasome. Exp. Gerontol. 2000, 35, 721-728. [CrossRef]

25. Arranz, L.; Naudí, A.; De la Fuente, M.; Pamplona, R. Exceptionally old mice are highly resistant to lipoxidation-derived molecular damage. Age 2013, 35, 621-635. [CrossRef]

26. Rodgers, K.J.; Dean, R.T. Assessment of proteasome activity in cell lysates and tissue homogenates using peptide substrates. Int. J. Biochem. Cell Biol. 2003, 35, 716-727. [CrossRef]

27. Kisselev, A.F.; Goldberg, A.L. Monitoring activity and inhibition of $26 \mathrm{~S}$ proteasomes with fluorogenic peptide substrates. Methods Enzymol. 2005, 398, 364-378.

28. Caniard, A.; Ballweg, K.; Lukas, C.; Yildirim, A.Ö.; Eickelberg, O.; Meiners, S. Proteasome function is not impaired in healthy aging of the lung. Aging 2015, 7, 776-792. [CrossRef]

29. Bulteau, A.L.; Szweda, L.I.; Friguet, B. Age-dependent declines in proteasome activity in the heart. Arch. Biochem Biophys. 2002, 397, 298-304. [CrossRef]

30. Petersen, A.; Honarvar, A.; Zetterberg, M. Changes in Activity and Kinetic Properties of the Proteasome in Different Rat Organs during Development and Maturation. Curr. Gerontol. Geriatr. Res. 2010, 2010, 230697. [CrossRef]

31. Li, F.K.; Davenport, A.; Robson, R.L.; Loetscher, P.; Rothlein, R.; Williams, J.D.; Topley, N. Leukocyte migration across human peritoneal mesothelial cells is dependent on directed chemokine secretion and ICAM-1 expression. Kidney Int. 1998, 54, 2170-2183. [CrossRef]

32. Grune, T.; Davies, K.J. The proteasomal system and HNE-modified proteins. Mol. Asp. Med. 2003, 24, 195-204. [CrossRef]

33. Kim, J.M.; Kim, H.G.; Son, C.G. Tissue-Specific Profiling of Oxidative Stress-Associated Transcriptome in a Healthy Mouse Model. Int. J. Mol. Sci. 2018, 19, 3174. [CrossRef] [PubMed]

34. Bendich, A. Physiological role of antioxidants in the immune system. J. Dairy Sci. 1993, 76, 2789-2794. [CrossRef]

35. Farout, L.; Friguet, B. Proteasome function in aging and oxidative stress: Implications in protein maintenance failure. Antioxid. Redox Signal. 2006, 8, 205-216. [CrossRef] [PubMed]

36. Lefaki, M.; Papaevgeniou, N.; Chondrogianni, N. Redox regulation of proteasome function. Redox Biol. 2017, 13, 452-458. [CrossRef] [PubMed]

37. Sala, A.J.; Bott, L.C.; Morimoto, R.I. Shaping proteostasis at the cellular, tissue, and organismal level. J. Cell Biol. 2017, 216, 1231-1241. [CrossRef]

38. Rodriguez, K.A.; Edrey, Y.H.; Osmulski, P.; Gaczynska, M.; Buffenstein, R. Altered composition of liver proteasome assemblies contributes to enhanced proteasome activity in the exceptionally long-lived naked mole-rat. PLoS ONE 2012, 7, e35890. [CrossRef]

39. Martinez de Toda, I.; Vida, C.; Ortega, E.; De La Fuente, M. Hsp70 basal levels, a tissue marker of the rate of aging and longevity in mice. Exp. Gerontol. 2016, 84, 21-28. [CrossRef]

40. Xirocostas, Z.A.; Everingham, S.E.; Moles, A.T. The sex with the reduced sex chromosome dies earlier: A comparison across the tree of life. Biol. Lett. 2020, 16, 20190867. [CrossRef]

41. Lemaitre, J.F.; Ronget, V.; Tidière, M.; Allainé, D.; Berger, V.; Cohas, A.; Colchero, F.; Conde, D.A.; Garratt, M.; Liker, A.; et al. Sex differences in adult lifespan and aging rates of mortality across wild mammals. Proc. Natl. Acad. Sci. USA 2020, 117, 8546-8553. [CrossRef] [PubMed]

42. Vina, J.; Gambini, J.; Lopez-Grueso, R.; Abdelaziz, K.M.; Jove, M.; Borras, C. Females Live Longer than Males: Role of Oxidative Stress. Curr. Pharm. Des. 2011, 17, 3959-3965. [CrossRef] [PubMed] 
43. Kayali, R.; Cakatay, U.; Uzun, H.; Genç, H. Gender difference as regards myocardial protein oxidation in aged rats: Male rats have increased oxidative protein damage. Biogerontology 2007, 8, 653-661. [CrossRef] [PubMed]

44. Silberstein, G.B.; Van Horn, K.; Hrabeta-Robinson, E.; Compton, J. Estrogen-triggered delays in mammary gland gene expression during the estrous cycle: Evidence for a novel timing system. J. Endocrinol. 2006, 190, 225-239. [CrossRef] [PubMed] 